\title{
Bimbingan Kelompok Untuk Mengurangi Kesulitan Belajar Siswa Kelas XI SMA Gajah Mada Gondomanan, Yogyakarta
}

\author{
Abi Apriyadi \\ Pascasarjana UIN Sunan Kalijaga Yogyakarta \\ abiaptiyadi@gmail.com
}

\begin{abstract}
Abstrak
Tujuan penelitian ini adalah untuk mengetahui bentuk-bentuk kesulitan belajar siswa SMA Gadjah Mada Gondomanan, Yogyakarta dan mendeskripsikan tentang langkah-langkah guru BK memberikan praktik bimbingan kelompok kepada siswa yang mengalami kesulitan belajar tersebut. Tujuannya diberikan kegiatan bimbingan kelompok oleh guru BK yakni untuk mengurangi kesulitan belajar siswa. Adapun metode penelitian ini menggunakan metode kualitatif deskriptif. Dengan teknik pengumpulan data menggunakan wawancara dan observasi. Hasil penelitian menunjukkan bahwa bentuk kesulitan belajar siswa terlihat dari kurang minat studi siswa pada studi pelajaran, kurang usaha dalam mengulangi pelajaran, dan waktu belajar yang tidak dimanfatkan dengan sebaik mungkin. Oleh karena itu, untuk mengurangi kesulitan belajar tersebut guru BK berusaha untuk menggunakan langkah-langkah bimbingan kelompok kepada lima siswa yang mengalami kesulitan belajar. Adapun hasil dari analisis penelitian ini adalah bahwa dengan guru BK SMA Gadjah Mada memberikan bimbingan kelompok kepada lima siswa yang mengalami kesulitan belajar dapat mengurangi kesulitan tersebut. Dimana perubahan tersebut dapat terlihat dari cara belajar, perubahan sikap sehari-hari, dan semangat belajar yang dimiliki mereka.
\end{abstract}

Kata Kunci: bimbingan kelompok, kesulitan belajar

\begin{abstract}
The purpose of this research is to know the difficulties of learning forms of high school students Gadjah Mada Gondomanan, Yogyakarta and describe the steps of the BK teacher to give group guidance to students who have difficulty learning The. The purpose of the group is to reduce
\end{abstract}


learning difficulties. As for this method of research using qualitative methods of descriptive. With data collection techniques using interviews and observations. The results showed that the student learning difficulties were seen from the lack of interest in student studies on lesson studies, less effort in repeating the lesson, and the best learning time was not made possible. Therefore, to reduce learning difficulties, BK teachers strive to use group guidance steps to five students who have difficulty learning. The result of the analysis of this research is that with the teacher of BK SMA Gadjah Mada give group guidance to five students who have difficulty learning can reduce the difficulty. Where these changes can be seen from the way of learning, daily attitudes changes, and the spirit of learning they possess

Keywords: Group guidance, difficulties of learning

\section{A. Pendahuluan}

Pendidikan merupakan usaha sadar dan terencana untuk mewujudkan suasana belajar dan proses pembelajaran dimana peserta didik dituntut secara aktif dapat mengembangkan potensi dirinya agar dapat memiliki kekuatan spiritual keagamaan pengendalian diri, kecerdasan, kepribadian, akhlak mulia serta keterampilan yang diperlukan bagi dirinya, masyarakat, bangsa, dan Negara. (Muhaimin, 2007: 5). Adapun pendidikan nasional berfungsi dalam mengembangkan kemampuan dan membentuk watak serta peradaban bangsa yang bermartabat dalam rangka mencerdaskan kehidupan bangsa, bertujuan untuk mengembangkan potensi peserta didik agar menjadi manusia yang beriman dan bertakwa kepada Tuhan Yang Maha Esa, berakhlak mulia, sehat berilmu, kreatif, cakap, mandiri dan menjadi warga Negara yang demokratis serta tanggung jawab.(Nuansa Aulia, 2008: 5).

Namun untuk mencapai tujuan pendidikan nasional di atas tidak terlepas dari komponen pendidikan dengan adanya guru, peserta didik, fasilitas dan lingkungan. Karena tujuan dari pendidikan tidak dapat tercapai dengan baik jika salah satu dari komponen tersebut tidak terpenuhi. Inti dari pendidikan adalah proses belajar mengajar. Tentu dalam proses belajar ini dibutuhkan kerjasama yang baik antara guru selaku pengajar dan siswa sebagai sasaran dari pendidikan. Guru sebagai pengajar dituntut untuk bisa menginternalisasikan materi pelajaran sesuai kurikulum dan silabus yang diberikan oleh sekolah. Maka dalam menyampaikan materi tersebut guru menggunakan strategi dan metode yang 
bervariasi sehingga adanya harapan para siswa dapat menguasai materi yang diajarkan oleh gurunya.

Oleh karena itu pada dasarnya setiap siswa berhak untuk memperoleh peluang dalam mencapai kinerja akademik yang memuaskan. Namun fakta yang terilihat dari kenyataan sehari-hari tampak jelas bahwa siswa itu memiliki perbedaan dalam hal kemampuan intelektual, kemampuan fisik, latar belakang keluarga, kebiasaan dan pendekatan belajar yang terkadang sangat mencolok antara seorang siswa dengan yang lainnya. (Muhibbin Syah, 2012: 185).

Oleh karena itu dengan adanya perbedaan kemampuan intelektual dan perbedaan latar belakang pribadi siswa seperti dijelaskan di atas. Walaupun guru telah menggunakan metode bervariasi dalam mengajar, hal yang tidak bisa dimungkiri bahwa tidak semua siswa dapat memahami dan menguasai pelajaran dengan baik. Perihal ini dinyatakan karena ada peserta didik yang tidak bisa meguasai pelajaran dengan baik sehingga hal ini dinamakan dengan kesulitan belajar. Dalam kegiatan pembelajaran banyak dihadapkan dengan sejumlah karakteristik yang beraneka ragam. Ada peserta didik yang dapat menempuh kegiatan belajarnya secara lancar dan berhasil tanpa mengalami kesulitan, namun disisi lain tidak sedikit pula peserta didik yang justru dalam belajarnya mengalami berbagai kesulitan. Kesulitan belajar siswa ditunjukkan dengan adanya hambatanhambatan tertentu untuk mencapai hasil belajar dan dapat bersifat psikologis, sosiologis, maupun fisiologis sehingga pada akhirnya dapat menyebabkan prestasi belajar yang dicapainya berada di bawah semestinya.

Adapun mengenai kesulitan belajar di sekolah bisa bermacam-macam yang dapat dikelompokkan berdasarkan sumber kesulitan dalam proses belajar, baik dalam hal menerima pelajaran atau dalam menyerap pelajaran. Dengan demikian pengertian kesulitan belajar diartikan sebagai kesukaran siswa dalam menerima pelajaran di sekolah. (Alisuf Subri, 2013: 88). Kesulitan belajar dapat diartikan sebagai suatu kondisi dalam suatu proses belajar yang ditandai adanya hambatanhambatan tertentu untuk mencapai hasil belajar. Hambatan-hambatan ini mungkin disadari dan tidak disadari oleh orang yang mengalaminya. Kesulitan belajar merupakan terjemahan istilah bahasa Inggris learning disability yang memiliki arti ketidak mampuan belajar. Maka ada beberapa isitlah pada kesulitan belajar: learning disorder (ketergangguan belajar) merupakan kekurangan yang tidak nampak secara lahiriah keterbelakangan yang mempengaruhi untuk menafsirkan yang dilihat dan didengar serta ketidakmampuan dalam menghubungkan berbagai informasi. Learning disabilities (ketidakmampuan belajar) seorang siswa yang 
mengacu kepada gejala siswa tidak mampu belajar (menghindari belajar), sehingga hasil belajarnya di bawah potensi intelektualnya. Learning disfunction (ketidakfungsian belajar) merupakan gejala proses belajar tidak berfungsi dengan baik meskipun pada dasarnya tidak ada tanda-tanda subnormalias mental, gangguan alat indera dan gangguan-gangguan psikologis lainnya. Under achiever (pencapain rendah) mengacu kepada siswa yang memiliki tingkat potensi intelekual di atas normal, tetapi prestasi belajarnya tergolong rendah. Slow learner (lambat belajar) siswa yang mengalami lambat dalam proses belajarnya sehingga ia membutuhkan waktu dibandingkan dengan siswa-siswa yang lain yang memiliki taraf potensi intelektual yang sama. (Derek Wood, 2009: 17).

Adapun Gejala-gejala kesulitan belajar ada beberapa ciri dan tingkah laku yang merupakan manifestasi dari gejala kesulitan belajar yakni menunjukkan hasil belajar yang rendah, hasil yang dicapai tidak seimbang dengan usaha yang dilakukan, lambat dalam melakukan tugas-tugas kegiatan belajar ia selalu tertinggal dengan kawan-kawanya dalam menyelesaikan tugas sesuai dengan waktu yang tersedia, menunjukkan sikap-sikap yang kurang wajar, dan menunjukkan tingkah laku yang berlainan, serta menunjukkan gejala emosional yang kurang wajar.

Peserta didik yang mengalami kesulitan belajar juga dapat dengan menunjukkan gejala kurang tahu bagaimana cara belajar yang tepat, membagi waktu belajar, menggunakan buku pelajaran, sulit untuk berkonsentrasi, kurang menyukai mata pelajaran tertentu dan lain sebagainya. Terkadang bentuk perilaku dalam kesulitan belajar yang dialami oleh peserta didik yakni dengan menunjukkan sikap menantang guru, membolos, kurang gembira, mudah tersinggung, pemarah, menunggu di luar kelas, tidak mau mencatat pelajaran, mengasingkan diri, tidak mau kerjasama dan tingkah laku kurang wajar lainnya. (Ahmad Widodo, 2012: 78).

Adapun peserta didik yang menunjukkan sikap gejala di atas disebut sebagai siswa yang mengalami kesulitan belajar. Tentu hal ini dipengaruhi oleh bearagam faktor yang menyebabkan terjadinya kesulitan belajar. Faktor-faktor yang menyebabkan kesulitan belajar pada siswa berdasarkan penelitian Muhammad Rizki dan kawan-kawan ada tiga faktor antara lain. Faktor biologis hambatan belajar ini disebabkan oleh kondisi fisik yang kurang baik yang dialami oleh siswa pada saat kegiatan belajar mengajar langsung. Kemudian adanya faktor psikologis yang meliputi kurangnya perhatian siswa dalam mendapatkan nilai, cara belajar siswa, dan bentuk kesiapan belajar yang kurang. Selanjutnya faktor 
lingkungan yang menyebabkan siswa mengalami kesulitan belajar yaitu dari lingkungan keluarga, lingkungan sekolah, dan lingkungan masyarakat. (Rizki dkk, 2014: 4-7).

Untuk mengurangi kesulitan belajar tersebut dibutuhkan kerjasama yang baik antar guru mata pelajaran, wali kelas, dan guru bimbingan dan konseling. Dimana guru mata pelajaran dan wali kelas lebih mengetahui keadaan peserta didik yang mana yang mengalami kesulitan belajar, sehingga mereka harus menyampaikannya kepada guru bimbingan dan konseling (BK). Dengan harapan guru BK dapat memberikan layanan bimbingan bersifat perbaikan belajar kepada siswa yang didiagnosis mengalami kesulitan belajar.

Maka dalam hal ini penulis melihat dari salah satu lembaga pendidikan di Yogyakarta yaitu SMA Gajah Mada Gondomanan, Yogyakarta. Karena lembaga pendidikan ini sudah barang tentu memiliki banyak permasalahan terkait dengan peserta didik, salah satunya mengenai kesulitan belajar yang terjadi pada beberapa siswa. Bagi penulis kesulitan belajar merupakan hal yang sangat penting untuk dieksplorasi, terlebih upaya guru BK melalui bimbingan kelompok untuk mengurangi kesulitan belajar yang dialami oleh siswa di sekolah tersebut.

Adapun pertanyaan yang akan dijawab dalam penelitian ini. Apa saja bentuk-bentuk kesulitan belajar yang dialami oleh siswa kelas XI di SMA Gadjah Mada? Kemudian Bagaimana langkah-langkah pemberian bimbingan kelompok yang dialakukan guru BK untuk mengurangi kesulitan belajar siswa kelas XI SMA Gadjah Mada?. Pertanyaan ini akan dijawab dalam konteks kesulitan belajar siswa dan melihat upaya guru BK di sekolah SMA Gadjah Mada dalam mengurangi kesulitan belajar tersebut melalui praktik bimbingan kelompok. Kemudian untuk pada penelitian ini penulis menggunakan metode penelitian field research (penelitian lapangan) dengan teknik analisis deskriptif kualitatif. Data penelitian yang terkumpul dianalisis dengan menggunakan pendekatan deduktif maupun induktif yang berkaitan dengan praktik bimbingan kelompok dalam mengurangi keuslitan belajar siswa kelas XI SMA Gadjah Mada.

\section{B. Pembahasan}

\section{Bimbingan Kelompok}

Mengenai bimbingan kelompok melalui kesulitan belajar penelitian sebelumnya sudah melakukan konteks bimbingan kelompok dalam kesulitan 
belajar. Dalam hal ini maka guru BK harus melewati proses tertentu dalam melaksanakan layanan bimbingan kelompok sesuai dengan prosedur yang telah diagendakan. Menurut prayitno bimbingan kelompok merupakan suatu layanan bimbingan yang diberikan kepada siswa secara bersama-sama atau kelompok agar kelompok tersebut menjadi besar dan mandiri. (Prayitno, 2009: 63). Dimana layanan bimbingan kelompok ini untuk mencegah berkembangnya masalah dan kesulitan pada diri siswa. Bimbingan kelompok dapat berupa penyampaian informasi atau aktivitas kelompok membahas masalah pendidikan, sosial dan lainnya. Dalam bimbingan kelompok para anggota kelompok (siswa) dapat diajak mengemukakan secara bersama-sama mengemukakan tentang suatu topik masalah untuk mengembangkan nilai dan langkah-langkah bersama untuk menangani permasalahan yang dibahas dalam kelompok. Adapun Proses layanan bimbingan kelompok dimana layanan bimbingan kelompok terdapat empat tahapan antara lain: a)Tahap pembentukan, pada tahapan ini para anggota saling memperkenalkan diri, penjelasan pengertian dan tujuan yang ingin dicapai dalam kelompok oleh pemimpin kelompok. b) Tahap peralihan, pemimpin kelompok harus berperan aktif membawa suasana, keseriusan dan keyakinan anggota kelompok dalam mengikuti kegiatan bimbingan kelompok. c) Tahap inti, tahap pembahasan masalah-masalah yang akan dibahas dalam bimbingan kelompok. d) Tahap pengakhiran, tahap ini merupakan akhir seluruh kegiatan bimbingan kelompok. Dimana pada tahap ini anggota kelompok mengungkapkan kesan dan pesan serta evaluasi akhir terhadap kegiatan bimbingan kelompok. (Tatiek Romlah, 2005).

Sedangkan Menurut Ahmad Juntika langkah-langkah bimbingan kelompok: a)Langkah awal. Dimulai dengan penjelasan tentang adanya bimbingan kelompok para siswa mengenai pengertian, tujuan dan kegunaan bimbingan kelompok. Setelah penjelasan tersebut merencanakan kesepakatan mengenai waktu dan tempat pelaksanaan bimbingan kelompok. b)Perencanaan kegiatan. Perncanaannya meliputi penetapan materi layanan, tujuan yang ingin dicapai, sasaran kegiatan, sumber yang digunakan, rencana penilaian serta waktu dan tempat. c) Pelaksanaan kegiatan. Pelaksanaan kegiatan menyeluruh meliputi persiapan fisik, bahan, keterampilan, dan administrasi. Kemudian tahap pembentukan kegiatan keterlibatan kelompok dan menjelaskan keadaan bimbingan kelompok serta membangun keakraban, kemudian tahap peralihan menjelaskan kegiatan selanjutnya, membahas suasana yang terjadi, dan meningkatkan kemampuan keikutsertaan anggota kelompok. Selanjutnya pada tahap kegiatan pimpinan kelompok mengemukakan masalah, Tanya jawab 
antar anggota dan mennyakan hal-hal yang belum jelas, selingan dan lain-lain. d) Evaluasi kegiatan meliputi penilaian dari hasil kegiatan bimbingan yang sudah dilakukan. (Juntika, 2007:23)

Maka dengan adanya prosses pemberian bimbingan kelompok tersebut diharapkan agar dapat membantu para siswa yang terlibat dalam bimbingan kelompok dapat menjadi lebih baik dan bisa mengurangi kesulitan belajar yang dialaminya.

\section{Bentuk-bentuk Kesulitan Belajar Siswa Kelas XI SMA Gadjah Mada Yogyakarta}

\section{a. Kurang minat pada studi tertentu}

Adanya sikap kurang minat pada mata pelajaran membuat siswa enggan untuk mengikuti pelajaran. Dimana sikap penolakan pada suatu pelajaran biasanya dipengaruhi oleh gaya atau metode pembelajaran yang diberikan guru bagi siswa yang lambat dalam memahami pelajaran merasakan bahwa metode yang guru berikan kurang dimengerti.

Beberapa siswa mengungkapkan bentuk keuslitan belajar karena kurang minat pada pelajar tersebut.

Para siswa yang bersangkutann yang mengalami hal tersebut cenderung lebih memilih tidak memperhatikan guru menjelaskan, kemudian terkadang lebih memilih izin keluar kelas dan tidak mengerjakan apa yang diperintahkan guru dengan alasan tidak menyukai bidang mata pelajaran tersebut. Sebenarnya dari diri mereka sendiri selalu berusaha untuk meminati beberapa bidang pelajaran namun hal itu tidak bisa dilakukannya. Karena hampir seluruh mata pelajaran yang ada semuanya sulit untuk dipahami. Oleh karena itu apakah hal ini karena dirinya lebih tertarik ke bidang olahraga dari pada harus belajar di kelas. Maka tidak dapat dimungkiri bahwa diantara mereka di kelasnya sering mendapatkan nilai yang selalu dibawah rata-rata sehingga sering menjadi langganan ujian ulang (remedial).

Dari penjelasan di atas, bahwa salah satu bentuk kesulitan belajar siswa kelas XI di SMA Gadjah Mada salah satunya yaitu kurang minat pada bidang studi mata pelajaran. Kemudian ditunjukkan sikap penolakan yang tampak dari kesulitan belajar tersebut. Sehingga siswa bersangkutan lebih memilih keluar kelas, tidak mau mendengar penjelasan guru dan tidak mau mencatat pelajaran. 
Adapun faktor yang mempengaruhi kurangnya minat belajar pada suatu mata pelajaran tertentu pada siswa yakni disebabkan oleh faktor inernal dan eksternal. Faktor internal meliputi keadaan fisik dan kondisi psikis siswa saat sedang belajar. Sementara pada faktor eksternal yang disebabkan oleh kondisi lingkungan keluarga, ekonomi, lingkungan sekolah, metode mengajar guru, media pembelajaran, materi pembelajaran, dan jadwal pelajaran. (Mahmud, 2015)

\section{b. Kurang ada usaha untuk mengulangi pelajaran di sekolah}

Setiap siswa pada umumnya selesai kegiatan belajar mengajar di sekolah langsung pulang ke rumah masing-masing. Dalam hal ini untuk lebih memahami suatu pelajaran yang belum dipahami seharusnya mengulangi materi pelajaran yang disampaikan oleh guru di sekolah dipahami di rumah.

Namun hal ini berbeda bagi siswa yang mengalami kesulitan belajar karena adanya alasan yang diungkapkan oleh siswa yang tidak pernah mengulangi pelajaran di rumah.

pada saat selesai sekolah, mereka tidak pernah di kontrol orangtua mereka mengulangi pelajaran atau tidak. Sehingga mereka merasa bahwa hal itu tidak terlalu penting. Di sisi lain ada beranggapan bahwa terlalu padatnya jadwal belajar, dimana selesai sekolah disuruh lanjut lagi untuk kursus dan sebagainya. Sehingga bagi yang bersangkutan hal ini membuat dirinya kelelahan dan bingung antara mata pelajaran di sekolah dan kursus mana yang harus diprioritaskan. Maka dirinya lebih cenderung tidak condong keduanya karena ia merasa bahwa dirinya juga lambat dalam memahami pelajaran di kursus dan apalagi di sekolah.

Dalam faktor lain penulis memperhatikan siswa yang mengalami kesulitan belajar. Siswa tersebut pada saat selesai sekolah harus melakukan pekerjaan lain yakni membantu orangtuanya bekerja. Disini fokusnya sudah terbagi dan secara fisik dia letih. Mungkin suatu pekerjaan tersebut terlalu banyak menyita waktu untuk dirinya belajar dan mengulangi mata pelajaran. Secara kebetulan siswa tersebut sering mengikuti remedial tugas mata pelajaran. (observasi, 2019)

Bentuk kesulitan belajar di atas, menjelaskan bahwa kurang perhatiannya keluarga juga menyebabkan anak saat setelah sekolah tidak mengulangi pelajaran di rumah. Sehingga ia merasakan kesulitan tersebut saat ujian dan sebagainya. Kemudian disisi lain pada saat keluarga mengharuskan anaknya mengikuti kursus dan pembelajaran yang terlalu padat memicu anak untuk memilih tidak belajar dengan serius. Dan ada faktor lain anak saat selesai sekolah langsung bekerja membantu orangutanya sikap tersebut memang baik akan tetapi karena lebih 
banyak waktu kerja sehingga anak yang bersangkutan lupa mengulangi pelajarannya.

Adanya Kurang perhatian orangtua terhadap cara belajar anak sama halnya orangtua kurang memotivasi anak di rumah untuk lebih giat belajar. Perihal ini disebabkan karena kesibukan orangtua dalam aktivitas kerja. Kemudian kurangnya pemahaman orangtua pentingnya dukungan belajar sehingga belum ada bentuk metode yang tepat dalam memperhatikan kesungguhan belajar pada anak. Selain itu juga perlunya dukungan dan kerjasama pihak sekolah dengan orangtua untuk siswa melakukan jam wajib belajar malam hari di tempatnya masing-masing. (Karmawan, 2012).

\section{c. Waktu belajar}

Kurang disipilinnya mengelola manajemen waktu belajar dapat menyebabkan siswa jauh tertinggal dari teman-teman di kelasnya. Perihal diungkapkan siswa yang kurang memanfaatkan waktu belajar yakni:

Pada saat di sekolah siswa yang bersangkutan lebih memilih bermain dengan teman-teman di lingkungan sekolah daripada fokus pada kegiatan belajar. Kemudian mereka juga menyatakan bahwa pengaruh paling besar kurangnya waktu belajar mereka karena dipengaruhi oleh game online dan lebih sering menggunakan gadget dan pemantauan sosial media.

Perihal di atas merupakan bentuk kesulitan belajar yang dipengaruhi oleh lingkungan sekolah yakni lingkungan berteman yang bersangkutan. Karena terlalu banyaknya waktu bermain daripada belajar sudah tentu prestasi belajarpun menurun bahkan dibawah rata-rata teman satu kelas. Kemudian penggunaan gadget secara berlebihan juga menyebabkan siswa lebih menghabiskan waktunya bersama gadget, permainan di Handphone. Maka waktu untuk belajar hampir tidak tersedia lagi karena mayoritas waktu belajar diperguanakan untuk main handphone atau android, sosial media dan game online. Disisi lain dalam hal ini sebenarnya peran orangtua juga penting dalam memperhatikan penggunaan handphone pada anak walaupun usianya telah beranjak remaja. Namun kontrol waktu untuk belajar jauh akan lebih penting.

Dampak negatif dari penggunan Handphone secara berlebihan terhadap kualitas belajar siswa akan menyebakan siswa tidak berkonsentrasi dengan proses pembelajaran. Apabila secara diam-diam siswa membawa handphone di sekolah maka mereka cenderung fokus ke handphone dan tidak mendengarkan penjelasan 
guru. Disisi lain juga sisi buruknya penggunaan handphone membuat perkembangan pribadi tidak peka dengan keadaan sekitar serta lingkungan masyarakat.(Maurus, 2017)

Dari penjelasan hasil penelitian di atas maka beberapa bentuk kesulitan belajar di atas terlihat bahwa beberapa siswa mengalami kesulitan belajar karena ada faktor internal dan eksternal yang membuat terjadinya kesulitan belajar. Adapun faktor-faktor yang mempengaruhi kesulitan belajar yaitu faktor internal dan eksternal: faktor internal meliputi kondisi jasmani, bakat, minat, motivasi, kondisi psikis, kemauan, intelegensi. Sedangkan faktor eksternal faktor keluarga, faktor lingkungan sekolah, dan faktor lingkungan masyarakat. (Mulyadi, 2011: 14).

Sehingga faktor-faktor ini menjadi penyebab terjadinya kesulitan belajar yang sering dialami oleh siswa. Maka selain untuk mengetahui bentuk kesulitan belajar siswa. Hasil penelitian ini juga bertujuan menjelaskan bahwa setiap bentuk kesulitan yang dihadapi siswa adanya faktor-faktor tertentu yang mempengaruhi siswa tersebut.

\section{d. Proses pemberian bimbingan kelompok oleh guru BK di SMA Gadjah Mada Gondomanan, Yogyakarta.}

\section{1) Pra-bimbingan}

Sebelum melakukan kegiatan bimbingan tentu guru BK perlu mempertimbangkan hal-hal yang harus dipersiapkan dalam melaksanakan bimbingan kelompok terhadap siswa yang mengalami kesulitan belajar. Persiapan pra bimbingan perlu dilakukan karena untuk penentuan kelancaran dalam keberlangsungan proses bimbingan yang akan dilaksanakan. Karena untuk mencapai tujuan diadakannya bimbingan kelompok agar dapat membantu siswa memahami masalah kesulitan belajar yang dihadapi mereka. Oleh karena itu proses kesiapan pra bimbingan ini sangat penting.

Perihal ini berdasarkan penjelasan dari guru BK SMA Gadjah Mada:

Bahwa pada tahap ini sebelum guru BK memeberi layanan bimbingan kelompok, guru BK mendapatkan informasi yang akurat terlebih dahulu dari guru mata pelajaran dan wali kelas. Karena pada tahap ini menurut Guru BK tersebut, hal ini tidak bisa ditentukan hanya satu pihak untuk memberikan layanan bimbinga kepada siswa. Maka perlunya kejelasan informasi dan mengecek kebenaran dari permasalahan yang dialami oleh siswa. Sudah barang tentu dengan demikian proses ini memerlukan pertimbangan, kerjasama, dan mufakat tentang kelayakannya siswa atau 
anak tersebut untuk mendapatkan bimbingan kelompok. Biasanya dalam hal ini guru BK memberi kesempatan kepada guru mata pelajaran untuk menjelaskan mengenai cara belajar siswa tersebut di dalam kelas, serta sikap yang tampak dari siswa yang mengalami kesulitan belajar. Setelah semua penjelasan dirasakan sudah jelas maka guru BK langsug mengindahkannya. Maka kemudian pada tahap selanjutnya guru BK melakukan diskusi dengan beberpa guru mata pelajaran serta wali kelas dari masing-masing siswa yang menngalami kesulitan belajar.

Maka dari penjelasan pendeskripsian wawancara di atas, bahwa sebelum melaksanakan bimbingan bimbingan guru BK melakukan prosedur awal yakni perlunya proses pra bimbingan yang didasarkan kesepakatan dan musyawarah antara guru mata pelajaran, wali kelas dan guru BK. Maka dengan adanya proses tersebut tentu ada sebuah harapan guru BK, guru mata pelajaran dan wali kelas dengan adanya persiapan dan meperhatikan siswa yang mengalami kesulitan belajar dengan melalui bimbingan kelompok diharapkan agar dapat membantu siswa mengurangi permasalahan tersebut.

Pra bimbingan merupakan proses perencanaaan akan melakukan bimbingan kelompok yang meliputi persiapan materi layanan, sasaran yang akan mendapatkan layanan bimbingan kelompok, bahan atau sumber yang akan mendapatkan bimbingan, serta perencanaan waktu dan tempat. Persiapan menyeluruh juga penting diperhatikan meliputi persiapan fisik, persiapan keterampilan, dan kelengkapan administrasi. (Juntika, 2007).

\section{2) Langkah Awal Bimbingan}

Pada tahap awal ini merupakan permulaan untuk melakukan kegiatan bimbingan kelompok terhadap siswa yang mengalami kesulitan belajar pada kelas XI SMA Gadjah Mada Yogyakarta. Dengan adanya rekapan data siswa, informasi tentang siswa, dan data lain yang berkenaan dengan kesulitan belajar yang dialami mereka. Maka siswa-siswa tersebut akan mendapatkan bimbingan kelompok. Infromasi siswa yang bersangkutan diperoleh guru BK berdasarkan informasi dan data dari guru mata pelajaran dan wali kelas.

Maka dalam hal ini guru BK langsung bertindak untuk memanggil/melakukan suatu tindakan siswa yang mengalami kesulitan belajar. Berdasarkan mufakat antara guru BK, guru mata pelajaran, dan wali kelas. Maka ada lima siswa yang memang mengalami kesulitan belajar yang diinformasikan dari guru BK dan wali kelas tersebut. Dalam hal ini juga untuk awal pelaksanaan 
bimbingan kelompok selain lima siswa tersebut guru BK juga memasukkan tiga siswa menjadi anggota bimbingan kelompok yang diakategorikan siswa yang memiliki prestasi belajar yang baik di sekolah.

Alasan memasukkan tiga siswa berprestasi tersebut berdasarkan penjelasan guru BK.

Pada saat bimbingan nantinya tiga siswa tersebut dapat memberikan masukan kepada teman-teman mengenai cara belajar mereka sehingga bisa mendapatkan hasil prestasi akademik yang baik. Untuk tahap ini pemberian bimbingan kelompok yang diberikan oleh guru BK kepada lima siswa yang mengalami kesulitan belajar bertempat di luar ruangan. Salah satu tempat pelaksanaanya yakni yaitu di taman sekolah. Karena pemilihan tempat ini akan membuat para anggota bimbingan kelompok merasa nyaman menurut guru BK SMA Gadjah Mada.

Dimana anggota kelompok yang mendapatkan bimbingan dapat lebih terbuka dalam mengemukakan pendapat dan mengungkapkan segala permasalahannya. Kemudian untuk waktu pemberian bimbingannya diberikan pada saat waktu istirahat/ waktu kerja bakti. Pemberian bimbingan tersebut tidak terlalu formal dan terlalu mengekang pada anggota kelompok. Maka suasananya dibuat senyaman mungkin agar para anggota kelompok dapat dengan jelas mengemukakan semua pendapat mereka. Kemudian guru BK juga menjelaskan bahwa dalam anggota bimbingan terdapat tiga siswa lain yang akan membantu teman-teman yang mengalami kesuluitan belajar. Kemudian guru BK menjelaskan kepada para anggota kelompok penjelasan mengenai bimbingan kelompok dan tujuan yang harus dicapai dalam kegiatan bimbingan kelompok tersebut. Selain itu juga guru BK melakukan negosiasi dalam kesepakatan waktu dan menegaskan untuk komitmen pada peneyelesaian satu masalah yang benar-benar membantu anggota kelompok yang mengalami kesulitan belajar. (Observasi, 2019)

Dari pendeskripsian hasil wawancara dan observasi dengan guru BK di atas, bahwa pada awal pelaksanaan bimbingan kelompok yang diberikan kepada siswa merupakan penjelasan mengenai tujuan dari bimbingan kelompok dan melakukan kontrak pelaksanaan kegiatan yang disepakati oleh masing-masing anggota. Kesepakatan pelaksanaan bimbingan kelompok tersebut yaitu dengan tujuan agar kesulitan belajar yang dialami siswa dapat berkurang.

Adapun langkah awal bimbingan kelompok dimulai dengan penjelasan tentang adanya pelaksanaan bimbingan kelompok bagi para siswa yang menjadi 
anggota kelompok. Maka guru BK selaku bimbingan kelompok menjelaskan mulai dari pengertian, tujuan, dan kegunaan dari bimbingan kelompok. Setelah penjelasan tersebut maka langkah yang perlu dilakukan yakni menghasilkan kelompok yang langsung merencanakan waktu dan tempat menyelenggarakan kegaiatan bimbingan kelompok.(Prayitno, 2007)

\section{3) Tahap inti/pelaksanaan Bimbingan}

Setelah dijelaskan mengenai tujuan dan negosiasi yang disepakati antara guru BK dan anggota bimbingan kelompok. Para anggota juga telah melakukan perkenalan diri maka guru BK mengadakan permainan ringan untuk membangun keakraban antar anggota kelompok. Permainan tersebut bertujuan agar sesama anggota kelompok dapat membangun kepercayaan satu sama lain.

Teknik bimbingan kelompok dilakukan dengan selingan berupa permainan dan lain sebagainya sebagai tujuan untuk memperkuat jiwa kelompok, memantapkan pembahasan. Ciri-ciri permainan bimbingan kelompok harus memenuhi ciri-ciri yang bersifat: sederhana, menggembirakan, menimbulkan suasana rilek dan tidak melelahkan, meningkatkan keakraban, dan harus diikuti oleh semua anggota kelompok. (Tohirin, 2013:167).

Kemudian untuk sistem bimbingannya sebagaimana dijelaskan guru BK:

Setelah mengemukakan pendapat dan mengungkapkan permasalahan siswa pada kesulitan belajar. Maka guru BK mempersilahkan tiga siswa berprestasi yang menjawab atas masalah yang diungkapkan oleh lima siswa yang mengalami kesulitan belajar. Maka untuk mengarahkan lebih kepada upaya mengurangi kesulitan belajar tiga siswa yang berprestasi diberikan waktu oleh pimpinan kelompok untuk menjelaskan dan mengajak teman-teman yang kesulitan belajar bagaimana teknik dan metode menyukai pelajaran dan selalu tekun dalam belajar sehingga bisa mendapatkan prestasi yang baik. Sehingga lima siswa yang mendengarkan pengalaman dari tiga siswa yang berprestasi tersebut dapat berusaha untuk mengikuti jejak teman-temannya yang memiliki semangat dalam belajar.

Jadi, pada saat proses bimbingan kelompok terjadinya saling tanya jawab dan saling tukar pendapat satu sama lain. Perlu diketahui meskipun bimbingan kelompok dilakukan pembahasannya melalui kegiatan berdiskusi, bertukar pendapat, tanya jawab namun semuanya bukan pada kesimpulan atau keputusan akan tetapi kepada arah konstruktif yang membina anggota kelompok yang sesuai dengan tujuan bimbingan kelompok. (Tohirin, 2013). 
Adapun sistem pelaksanaan bimbingan kelompok pada tahap ini yang dilakukan guru BK yakni:

\begin{abstract}
Apabila waktu yang diberikan dirasakan cukup oleh guru BK. Maka guru BK juga langsung melakukan klarifikasi dan maksud dari penyelesaian untuk mengurangi kesulitan belajar siswa. Hal ini disampaikan dalam bentuk ceramah dan siswa yang bersangkutan diperbolehkan menanyakan hal-hal yang kurang jelas. Teknik tanya jawab dengan guru BK ini juga dilakukan sebelum guru BK mengakhiri bimbingan kelompok pada saat itu. Sehingga diharapkan siswa benar-benar mendapatkan suatu perubahan yang lebih baik dari sebelumnya dengan pelaksanaan bimbingan kelompok tersebut.
\end{abstract}

Melalui adanya teknik pelaksanaan mekanisme bimbingan kelompok di atas diharapkan siswa yang mengalami kesulitan belajar dapat mengurangi kesulitan yang mereka alami. Harapan lain juga dengan pelaksanaan ini guru BK berharap anak-anak yang mengalami kesulitan belajar dapat memiliki semangat belajar setidaknya dapat memperbaiki dari keadaan sebelum-sebelumnya.

\title{
4) Tahap evaluasi
}

Tahap ini dilakukan setelah pelaksanaan bimbingan kelompok. Maka pada tahap ini guru BK melihat sejauh mana perkembangan lima siswa tersebut setelah mendapatkan bimbingan kelompok. Ada perubahan perilaku yang terjadi setelah bimbingan kelompok.

Berdasarkan penjelasan guru BK yang melakukan evaluasi perubahan perilaku yang signifikan yang dialami siswa dari keadaan kesulitan belajar tersebut:

Dari beberapa siswa yang mengalami kesulitan belajar terlihat semangat belajarnya mulai tinggi dan prestasi belajarnya agak sedikit membaik. Kemudian mereka juga lebih sering berteman dengan tiga temantemannya yang masuk ke dalam anggota bimbingan kelompok mereka. Sehingga secara langsung tentu hal ini berpengaruh positif untuk mengurangi kesulitan belajar yang dialami mereka sebelumnya.

Teman-teman lain yang mengungkapkan dan merasakan perubahan cara memahami pelajaran pada lima siswa yang mengalami kesulitan belajar yaitu:

Pada saat di kelas diantara mereka sudah mengurangi perilaku malas mencatat, enggan mendengarkan guru, menentang guru dan sebagainya yang merrupakan perilaku dari sikap penolakan terhadap kesulitan 
belajar. Kemudian yang bersangkutan lebih sering bertanya kepada kami mengenai pelajaran yang belum dipahami mereka. Maka dengan senang hati kamipun membantu mereka dengan adanya semangat untuk berusaha memahami pelajaran yang belum dipahami.

Tentu perihal ini merupakan suatu tujuan adanya dengan adanya bimbingan kelompok tersebut untuk mengurangi faktor kesulitan belajar pada lima anak tersebut. Dimana sebelum mendapat bimbingan mereka sering keluar kelas karena tidak suka gaya pembelajaran yang disampaikan, sering tidak menulis dan tidak mendengar, dan sikap penolakan belajar lainnya. Perlahanlahan sudah sedikit berkurang ditampakkan oleh mereka. Sehingga tujuan dari bimbingan kelompok yang diberikan dapat mengurangi diri mereka dari kesulitan dalam belajar yang mereka alami selama ini.

Bentuk keberhasilan bimbingan kelompok yang dilaksanakan di SMA Gadjah Mada untuk mengurangi kesulitan belajar selaras dengan tujuan dari bimbingan kelompok. Dimana tujuan bimbingan kelompok Menurut Bennet yaitu: memberikan kesempatan-kesempatan pada siswa untuk belajar hal-hal yang berkaitan dengan masalah pendidikan, pekerjaan, pribadi dan sosial. Kemudian tujuan bimbingan kelompok untuk memberikan layanan-layanan pengurangan suatu masalah, penyembuhan, maupun pencegahan melalui kegiatan bimbingan kelompok. (Tatiek Romlah, 2005).

\section{Simpulan}

Berdasarkan hasil penlitian dan pembahasan yang telah di deskripsikan di atas dengan melaui hasil analisis data wawancara dari informan dan observasi maka dapat disimpulkan bahwa bentuk kesulitan belajar siswa di SMA Gadjah Mada yaitu kurang minat pada bidang mata pelajaran, kurang usaha dalam memahami pelajaran, dan faktor waktu belajar. Kemudian langkah-langkah bimbingan kelompok yang diberikan oleh guru BK tersebut dapat mengurangi kesulitan belajar yang dihadapi oleh lima siswa kelas XI. Perubahan tersebut dilihat dari cara belajarnya yang sudah mulai lebih baik dan berkurangya sikap tampak yang menentang aturan kegiatan belajar mengajar. Dari hasil penelitian ini juga dapat disimpulkan bahwa bimbingan kelompok yang dilaksanakan oleh guru BK dapat membantu siswa yang mengalami kesulitan belajar untuk menguragi masalah kesulitan tersebut. 


\section{DAFTAR PUSTAKA}

Ahmadi Abu dan Widodo Supriyono, 2012. Psikologi Belajar, Jakarta: Rineka Cipta.

Juntika Achmad Nurihsan, 2007. Bimbingan dan Konseling dalam Berbagai Latar Kehidupan Bandung: Refika Aditama.

Karmawan dan Supridai, 2012. "Peranan Keluarga Dalam Meningkatkan Motivasi Belajar Siswa (Studi SDN 2 Mengkudu, Sambas" (Jurnal Tesis, PMISUNTAN-PSS).

Mahmud Haris, Nurhayati Tine, 2015. "Faktor-faktor Yang Mempengaruhi Kurangnya Minat Belajar Siswa Pada Mata Pelajaran IPS Di SMPN 3 Gorontalo" (Artikel Jurnal KIM Fakultas Ilmu Pendidikan).

Muhaimin, 2007. Pengembangan Kurikulum Pendidikan Agama Islam Di Sekolah Madrasah Dan Perguruan Tinggi, Jakrta: Rajawali Press.

Mulyadi, 2011. Diagnosis Kesulitan Belajar dan Bimbingan terhadap Kesulitan Belajar Yogyakarta: Nuha Litera.

Prayitno, 2009. Layanan Bimbingan dan Konseling Kelompok Edisi Revisi, Jakarta: Ghalia Indonesia.

Rizki Muhammad dkk, 2014. "Faktor-faktor Penyebab Kesulitan Belajar Peserta Didik pada Mata Pelajaran Menggambar Teknik (Studi kasus siswa kelas X TGB SMKN 1 Jakarta", (Jurnal Edukasi Problem Peserta didik).

Romlah Tatiek, 2005. Teori dan Praktek Bimbingan Kelompok, Malang: Universitas Negeri Malang.

Subri Alisuf, 2013. Psikologi Pendidikan, Jakarta: Pedoman Ilmu Jaya.

Syah Muhibbin, 2012. Psikologi Belajar, Jakarta: RajaGrafindo.

Tim Redaksi Nuansa Aulia, 2008. Himpunan Perundang-Undangan RI Tetntang Sistem Pendidikan Nasional UU.RI No. 20 Tahun 2003, Bandung: Nuansa Aulia.

Tohirin, 2013. Bimbingan dan Konseling di Sekolah dan Madrasah (Berbasis Integrasi), Jakarta: PT RajaGrafindo Persada.

Wood Derek, 2009. Kiat Mengatasi Gangguan Belajar, Yogyakarta: Kata Hati. 